\title{
HOSPICJUM JAKO FORMA OPIEKI PERINATALNEJ W CELU ZAPOBIEGANIA ZJAWISKU ABORCJI
}

\begin{abstract}
Streszczenie
Autor, wychodzac z faktu, iż dla wielu kobiet poród jest trauma, wiązaca się z dylematem urodzić czy usunać chore letalnie dziecko, rozważa rolę hospicjum perinatalnego. Stawia teze, iż takie ośrodki pomocy przyczyniaja się zapobieganiu zjawisku aborcji. Jeśli kobieta zostanie pozostawiona z tak wielkim problemem sama, naraża się na decyzję o radykalnym rozwiązaniu problemu. Jeśli dostanie odpowiednie duchowe i materialne wsparcie, zwykle godzi się na urodzenie dziecka, a potem na jego godne pożegnanie (nie wykluczajac, jeśli jest wierzaca, sakramentu chrztu św.). Jest to ważna pomoc, jaka kobiety moga otrzymać (dziś wsparta polityka spoleczna rzadu polskiego), w alternatywie bowiem pozostaja programy, proponujace takiej matce aborcje, jako jedyne stuszne rozwiazanie. Aborcja jednak nie rozwiazuje sprawy, często li tylko pomnaża dramat matki, obciażajac ją kolejnymi następstwami: moralnymi, psychologicznymi oraz somatycznymi.
\end{abstract}

Słowa kluczowe: aborcja, hospicjum perinatalne, polityka państwa, opieka nad matka, etyka

\section{Wstęp}

Punkt wyjścia dla niniejszych rozważań stanowi fakt, że wiele kobiet boi się (a nawet bardzo boi się) porodu. Niektóre z nich lękają się czy sobie poradzą i mają

* Ks. Stanisław Biały - dr hab. teologii moralnej, prof. UKSW, Katedra Antropologii i Bioetyki, Wydział Studiów nad Rodziną, Uniwersytet Kardynała Stefana Wyszyńskiego w Warszawie. 
zły nastrój nawet po narodzinach dziecka1. Co więcej, poród niektóre kobiety przeżywają jako swoistą traumę: $10-15 \%$ ma po nim depresję. Jeszcze gorzej jest, kiedy stają one przed perspektywą urodzenia dziecka z wadą letalną (tj. taką, która prowadzi do śmierci). Co może pomóc im w takiej sytuacji? Czy jest jakaś instytucja, która może podać im rękę w tak trudnym i bolesnym doświadczeniu? Tak oto dochodzimy do roli, jaką pełnią hospicja perinatalne. Wydaje się, że ich pomocowe znaczenie jest tutaj niezwykle ważne. Kobiety bowiem przed dylematem aborcji stają w szczególności wtedy, gdy pozostają osamotnione z ewentualnością urodzenia ułomnego i śmiertelnie chorego dziecka. Stawiamy niniejszym pytanie, czy pomoc, jaką stanowią tego typu hospicja, może odstręczyć je od takiej dramatycznej decyzji? A jeśli tak, to pod jakim szczegółowym warunkiem? I jest to bardzo ważne zagadnienie, jako że po drugiej stronie dyskursu etycznego znajdują się programy lansujące aborcję, tzn. jako szybkie i jedyne dobre rozwiązanie, tej bardzo złożonej pod względem materialnym, społecznym, moralnym itp. sytuacji. Zatem szukając adekwatnych odpowiedzi mamy świadomość, że po jednej stronie znajdują się hospicja perinatalne, które mają dużą szansę przebić się ze swoją propozycją obrony życia, a po drugiej zorganizowane ideologie, które, jeśli nawet (jak zakładamy) propagują coś w dobrej wierze, np. w imię troski o prokreacyjne zdrowie kobiety, to i tak pozostawiają pytanie, czy ich motywacja ma naukowe podstawy (medyczne i etyczne) do bycia nazwaną czynem dobrym? (Por. Platforma Działania, Pekin 1995, art. 106 c $)^{2}$.

1 S.Y. Abrams - T. Field - F. Scafidi - M. Prodromidis, Newborns of depressed mothers, "Infant Mental Health Journal" 16 (1995), s. 233-239; Depresja poporodowa-cała prawda, http://www.edziecko.pl/ciaza_i_porod (3.02.2015).

2 Platforma działania $\bar{i}$ deklaracja pekińska: Czwarta Światowa Konferencja ws. Kobiet, Pekin 4-15 wrzesień 1995 r.; http://www.federa.org.pl/nasze-publikacje/broszury-ulotki-ksiazki/380-zdrowie-reprodukcyjne-kobiet(10.11.2010); art. 106 c; tamże: „W zakres opieki nad zdrowiem reprodukcyjnym wchodzą: wysokiej jakości usługi planowania rodziny, w tym: poradnictwo, edukację oraz dostęp do właściwie przekazywanej informacji; opieka nad kobietą w ciąży, bezpieczny poród oraz opieka po porodzie; opieka prenatalną nad płodem, opieka nad noworodkiem, karmienie piersią; zapobieganie i leczenie niepłodności; zapobieganie niepożądanej ciąży; możliwość bezpiecznego przerywania ciąży; leczenie infekcji narządów rodnych, chorób przenoszonych drogą płciową i innych dolegliwości układu rozrodczego; informacja i poradnictwo dotyczące seksualności człowieka, odpowiedzialnego rodzicielstwa oraz zdrowia reprodukcyjnego i seksualnego; profilaktyka i leczenie nowotworów narządów płciowych oraz raka piersi”; por. J. KrzyżanowskaZbucka, Problemy emocjonalne kobiet w okresie okołoporodowym, Warszawa 2008; tamże, s. 9: „Wsparcie innych osób, rodziny i przyjaciół, pracodawcy, a także wsparcie społeczne i różnych instytucji pomocowych to kolejny, bardzo istotny składnik zasobów odporności. 


\section{Wyjaśnienie podstawowych użytych pojęć}

Pierwszym, istotnym dla adekwatnego zrozumienia podejmowanej problematyki pojęciem, które należy niniejszym dookreślić, jest opieka okołoporodowa. Mówiąc zamiennie - perinatalna, bowiem przymiotnik perinatalny (z języka angielskiego lub hiszpańskiego) znaczy okołoporodowy. Jest to działanie, które ma na celu zapewnianie kobiecie, która spodziewa się dziecka, kompleksowej pomocy; a już w szczególności, gdy jest ono obarczone wadą letalną, czyli taką, która nieuchronnie prowadzi do jego szybkiej śmierci. Opieka taka rozgrywa się na trzech poziomach, a jej czas jest odpowiednio podzielony. W związku z tym mamy: opiekę prekoncepcyjną (sprzyjającą zajściu w ciążę), opiekę przedporodową, opiekę śródporodową, opiekę poporodową, opiekę nad noworodkami i niemowlętami do pierwszego roku życia. W jej kontekst (tym samym) wpisuje się analogiczny termin, którym jest: okres okołoporodowy. Pomaga on rozeznać kolejne etapy postępowania w zakresie samego porodu. I tak w zależności od przyjętej definicji zakłada się, że jest to czas: a) obejmujący ostatni trymestr ciąży, sam poród oraz pierwsze siedem dób życia pozamacicznego; b) obejmujący przedział między 20. a 28. tygodniem po zapłodnieniu komórki jajowej, a kończy się między 1. a 4. tygodniem po urodzeniu dziecka ${ }^{3}$.

Opieka okołoporodowa jest sprawowana przez lekarzy perinatologów, neonatologów, wykwalifikowane położne itp. Zajmuje się profilaktyką oraz leczeniem matki, płodu i dziecka w okresie przedkoncepcynym, podczas ciąży, porodu i połogu. Do zadań perinatologii należy uzyskanie wysokiej jakości opieki nad matkami, płodami i noworodkami, maksymalne wykorzystanie wyposażenia i personelu o wysokich kwalifikacjach oraz drogiej aparatury do intensywnej opieki medycznej. Już w 1989 r. wyszło zbiorowe dzieło, pt. „Medycyna perinatalna”, pod redakcją Zbigniewa Słomko, złożone z II tomów, liczące 1780 stron. W nim całość zagadnień medycyny perinatalnej podzielono na dwie części: fizjopatologię położniczą, obejmującą opiekę nad matką i płodem oraz neonatologiczną, tj. sferę działalności w zakresie fizjologii noworodka w okresie poporodowym ${ }^{4}$.

To, czy kobiety w ciąży i matki małych dzieci z niego korzystają, zależy głównie od obiektywnej dostępności wsparcia, ale także w dużej mierze od nich samych".

3 Okres okołoporodowy, https://pl.wikipedia.org/wiki/Okres_oko\%C5\%82oporodowy; por. T. Dangel, Opieka paliatywna w onkologii dziecięcej, „Opieka Paliatywna nad dziećmi”, XIV (2006), s. 48-56.

4 Medycyna perinatalna, red. Z. Słomko, t. 2, Warszawa 1989, por. K.M. KuczkowskiL. Drobnik, Anestezjologia w położnictwie i medycynie perinatalnej. Zasady i praktyka, Warszawa 2009. 
Następne pojęcie, to hospicjum perinatalne. Oznacza ono strukturę, w której odbywa się opieka nad śmiertelnie chorym dzieckiem. Mówimy więc o prowadzonej w nim hospicyjnej opiece okołoporodowej lub hospicyjnej opiece perinatalnej (paliatywnej). Jest to też system wsparcia medycznego i psychicznego względem kobiety, będącej w stanie błogosławionym (lub podobnie połogowym), gdy życie jej dziecka jest poważnie zagrożone. Ale to także odpowiednio zorganizowane wsparcie jej męża, a nawet jej bliskich. Hospicjum perinatalne - to niniejszym budynek, personel, pacjent, ale także (a może nade wszystko) kryteria działania, gdzie podstawowym wyznacznikiem już nie jest działanie lecznicze doświadczonych i wykształconych lekarzy (np. nad chorym dzieckiem), co obecność takich ludzi, którzy są $\mathrm{w}$ stanie $\mathrm{z}$ pomocną empatią towarzyszyć poszczególnym pacjentom w ich trudnym, a nadto bardzo odpowiedzialnym momencie życia. Jednak taka opieka (tzn. mająca jasno określony cel paliatywny) z zasady nie może wykluczać wymiaru terapeutycznego. Nawet wtedy, gdy już jest bezspornie przesądzone, że dziecko w niedługim czasie umrze. Nadto jest do podkreślenia, że w Polsce rozwój niniejszych placówek (m.in. opracowywanie właściwych kryteriów działania) wspiera Instytut na Rzecz Kultury Prawnej Ordo Iuris.

Trzecie relatywnie ważne pojęcie, mające swe zastosowane w tym artykule, to zjawisko aborcji. Niestety, w kwestii opieki nad kobietą z zagrożoną ciężą, nie sposób nie zauważyć, że są takie kraje, gdzie około 70\% ciąż kończy się aborcją! Rosyjski raport o śmierci i moralności - stwierdza: „Rosja to kraj o najwyższym wskaźniku aborcji na świecie. Mimo że nie istnieją tam żadne ograniczenia w zakresie używania prezerwatyw i pigułek antykoncepcyjnych, aborcja pozostaje chętnie stosowaną metodą antykoncepcji. Niestety, wiek inicjacji seksualnej obniża się, a ponieważ w Rosji nie istnieje edukacja seksualna, z problemem niechcianej ciąży muszą mierzyć się coraz młodsze dziewczęta. Rozwiązanie problemu wydaje się tym trudniejsze, że aborcja w rosyjskim społeczeństwie wciąż pozostaje tematem tabu"s. Niniejszym przykład ten (tak wymowny) służy nam do tego, aby postawić pytanie, czy można, kształtując sytuację w Polsce, wpłynąć na przebieg sytuacji okołoporodowej w innych krajach, także w Rosji? Szczególnie że coraz częściej mówimy o problemie aborcji widzianej jako element polityki prorodzinnej, co jest dramatycznie przykrym paradoksem etycznym, nakazującym w imię dobrego celu (jakim jest rodzenie tylko zdrowych dzieci) uświęcać złe środki (jakim jest zabijanie chorych).

\footnotetext{
5 Rosyjski raporto śmierci i ,,moralności”: około 70\% ciąży kończy się aborcja, http:// www.fokus.tv; http://www.pch24.pl/rosyjski-raport-o-smierci-i-moralnosci--okolo-70--ciaz-ko nczy-sie-aborcja (23.09.2016).
} 
Nadto chcąc podkreślić ważność oraz specyfikę podejmowanej tu problematyki, trzeba zauważyć, że w zakres pojęcia opieka okołoporodowa wchodzi problem przyznania poczętemu dziecku prawa do: a) urodzenia się, b) w rodzinie, c) w rodzinie złożonej z ojca i matki. A nadto, że można tutaj mówić o całym kompleksie uprawnień takiej osoby, czyli o Karcie Praw Dziecka Umierającego ${ }^{6}$. Dotykamy tu najbardziej podstawowego prawa, jakim jest prawo do życia oraz wielu innych uprawnień wynikających z godności tegoż życia (przyrodzonej i nadprzyrodzonej). Wszystkie one powinny być adekwatnie dostrzeżone i chronione, jeśli chcemy mówić o profesjonalizmie opieki nad bezbronną istotą ludzką, oddaną bezgranicznie wrażliwości dorosłych: matce, ojcu, lekarzom, społeczeństwu. Czyli, jeśli chcemy mówić o dobrze rozumianej jakości opieki okołoporodowej, prowadzonej dzisiaj w różnych ośrodkach hospicyjnych; w Polsce, ale nie tylko.

\section{Działanie hospicjów perinatalnych w Polsce}

Polska jest krajem, gdzie coraz więcej poczyna się dzieci z wadami wrodzonymi, nie wykluczając tych, które bezpośrednio prowadzą do śmierci. „Specjaliści alarmują: to będzie narastający problem społeczny, ponieważ system opieki społecznej nie jest wystarczający"7. Gdy dołączymy do tego jeszcze inne przypadki ciężkich (nabytych z różnych przyczyn) chorób, to nie dziwi, że rozwija się i upowszechnia tzw. polski model perinatalnej opieki paliatywnej. Mówi się wręcz o paradoksie: lepsza opieka więcej chorób. Np. w 2005 roku w hospicjach domowych leczono 83 dzieci z wadami wrodzonymi i aberracjami chromosomowymi, w roku 2006 już 110, a obecnie grupa ta stanowi około $20 \%$ wszystkich dzieci leczonych przez hospicja domowe. Przewiduje się, że w następnych latach liczebność tej grupy będzie jeszcze wzrastać ${ }^{8}$. Zatem w opiece perinatalnej hospicyjnej (paliatywnej) chodzić będzie o objęcie właściwą troską rodziny i dziecka w sytuacji uzyskania niepokojącej diagnozy prenatalnej, co „stanowi pełną realizację zasad wynikających z art. 39 Kodeksu Etyki Lekarskiej oraz preambuły do Konwencji o Prawach

6 Karta praw dziecka umierającego, „Więź” 589 (2007), s. 11-12; J. SzymkiewiczDangel, Perinatalna opieka paliatywna - czy możliwa jest współpraca położników i neonatologów z hospicjami domowymi dla dzieci?, w: Opieka Paliatywna nad Dziećmi, red. T. Dangel, Warszawa 2007, s. 28.

7 E. Rycerz, specjaliści: rodzi się coraz więcej dzieci z chorobami genetycznymi, http:// parenting.pl/specjalisci-rodzi-sie-coraz-wiecej-dzieci-z-chorobami-genetycznymi (2017).

8 L. Szot, Powstanie i rozwój ruchu hospicyjnego, „Studia Warmińskie” XLVI (2009), s. 226 -237; por. E. Rycerz, specjaliści: rodzi się coraz więcej dzieci z chorobami genetycznymi, art. cyt., https://parenting.pl/. 
Dziecka. Perinatalna opieka hospicyjna pozwala na pełne upodmiotowienie matki oraz dziecka poczętego, będącego pacjentem posiadającym prawo do godnej śmierci"'.

W kontekście skokowego rozwoju chorób cywilizacyjnych potrzeba ośrodków, które mogłyby nieść skuteczną pomoc perinatalną paliatywną jest ogromna. Jednak z informacji, które wynikają z rozmowy w Polskim Radio 24. z Bogną Kozłowską (z Hospicjum im. E. Dutkiewicza SAC w Gdańsku) i o. dr. Filipem Buczyńskim (z Ogólnopolskiego Forum Pediatrycznej Opieki Paliatywnej), można wysnuć, że obecnie w Polsce hospicja perinatalne znajdują się poza systemem opieki zdrowotnej. Tego typu działalność nie jest finansowana przez państwo, a ośrodki ją prowadzące utrzymują się w ramach działalności charytatywnej. Np. w roku 2016 taką opiekę prowadziło (wg. Badań Instytutu Ordo Iuris) czternaście hospicjów. Czuwały nad tym fundacje i stowarzyszenia, a przypadki, którymi się owe hospicja się zajmowały, obejmowały najcięższe wady wrodzone. Nadto w praktyce (na dzień dzisiejszy) trudno jest precyzyjnie oszacować, ile takich punktów pomocowych działa. Te, których praca daje się monitorować są w dużych miastach, m.in. w Warszawie, Łodzi, Krakowie, Rzeszowie, Katowicach, Gdańsku, Poznaniu itp. Chodzi o to, że: „na terenie Polski, z każdym rokiem przybywa organizacji pozarządowych, które oferują tego rodzaju pomoc. Podobnych hospicjów najczęściej nie wyodrębnia się poprzez miejsce, budynek, oddziały, itd. Jak wskazują znawcy tematu, chodzi tu raczej o filozofię działania, filozofię wsparcia"10.

Więcej o działaniu takich ośrodków pomocy można dowiedzieć się np. z rozmowy Beaty Zajączkowskiej z krajowym duszpasterzem hospicjów ks. Piotrem Krakowiakiem. Jego zdaniem taka działalność to konsekwencja założeń hasła: „Hospicjum to też życie”, które od lat propaguje ruch hospicyjny. Jak zauważa: „Ruch hospicyjny kojarzymy głównie z opieką nad dorosłymi chorymi na nowotwór w ostatniej fazie życia. Działają jednak także hospicja dziecięce, gdzie otaczamy opieką paliatywną najmłodszych. Kolejne wyzwania stawia przed nami diagnostyka prenatalna. Daje ona szansę, by wiele schorzeń wyleczyć jeszcze w łonie matki, żeby poprawić jakość życia, czy wręcz by uratować dziecko. Niestety,

9 B. Kmieciak - Z. Szafrańska-Czajka, Raport. Perinatalna opieka hospicyjna: wizja, działania oraz wyzwania, Warszawa 2016, s. 25-26 nn; por. Konwencja o prawach dziecka, przyjęta przez Zgromadzenie Ogólne Narodów Zjednoczonych dnia 20 listopada 1989 r., Dz. U. $1991 \mathrm{nr} 120$ poz. 526.

10 B. Kmieciak - Z. Szafrańska-Czajka, Raport. Perinatalna opieka hospicyjna: wizja, działania oraz wyzwania, dz. cyt., s. 24; por. L. Szot, Powstanie i rozwój ruchu hospicyjnego, dz. cyt., s. 226 -237; D. Kornas-Biela, Wokół początków życia ludzkiego, Warszawa 2002. 
czasami ta diagnostyka daje odpowiedzi bardzo trudne dla matki: że dziecko będzie trwale niesprawne; że jest bardzo uszkodzone; że jego szanse na przeżycie są niewielkie"ll. Chodzi o to, że jeśli przeciwnicy diagnostyki prenatalnej mówią $\mathrm{w}$ tej sytuacji, że jest ona niegodziwa, ponieważ w jakiś sposób sugeruje, żeby dokonać aborcji, to działalność hospicjów perinatalnych jest tu czymś takim, co odpowiada na taki zarzut czynnie: „oferując (konkretną) pomoc rodzinom, które otrzymują hiobową wieść".

A jak - w konkrecie jeszcze bardziej uszczegółowionym - działają hospicja perinatalne, chcące uskuteczniać pomoc paliatywną? Tu przykładem może być: Hospicjum Perinatalne Łodzi, prowadzone przez Fundację Gajusz Łódź. Ma ono pod opieką te rodziny, u których rozpoznano letalną wadę płodu. Opieka taka polega na udzielaniu paliatywnego wsparcia rodzicom jeszcze przed urodzeniem się ich dziecka. Tu wsparcie ma następujące etapy:

a. wyjaśnienie specyfiki choroby dziecka, rokowania oraz możliwych scenariuszy postępowania,

b. zapewnienie profesjonalnej pomocy psychologicznej,

c. omówienie zasad opieki hospicyjnej,

d. przygotowanie domu i wyposażenia w sprzęt niezbędny do opieki nad chorym noworodkiem,

e. zapewnienie pomocy socjalnej i duchowej,

f. umożliwienie kontaktu z innymi rodzicami, których dziecko zostało dotknięte wadą letalną ${ }^{12}$.

Natomiast dla matki, u której rozpoznano jedynie podejrzenie wystąpienia wady letalnej u płodu, opieka wygląda następująco:

a. konsultacje lekarza genetyka;

b. USG genetyczne płodu i badania biochemiczne;

c. konsultacje lekarza ginekologa-położnika;

d. konsultacje lekarzy pediatrów;

e. konsultacje psychologiczne ${ }^{13}$.

Jednak opieka perinatalna jak i medycyna perinatalna są to dziedziny w lecznictwie na tyle nowe, że zarówno pediatryczna opieka paliatywna jak i perinatologia są nadal niedocenianymi dziedzinami medycyny. W 2007 r. Joanna

1 A. Wiejak, Sa alternatywy dla aborcji i pozostaja nieznane, „Moja Rodzina”, 12 (2014), s. 12-14; por. L. Szot, Powstanie i rozwój ruchu hospicyjnego, dz. cyt., s. $231 \mathrm{nn}$.

12 Hospicjum perinatalne Łodzi-fundacja Gajusz Łódź, http://www.gajusz.org.pl/dla-potrzebujacych/hospicjum-perinatalne; por. J. Zaremba, Genetyczna diagnoza. Badania prenatalne w Polsce, „Panorama Medyczna”, 2 (2006), s. 12-15.

13 Tamże. 
Szymkiewicz-Dangel z II Kliniki Położnictwa i Ginekologii Akademii Medycznej w Warszawie, pisała w tym kontekście następująco: „Niewielu lekarzy, reprezentujących te dwie, pozornie odległe dziedziny, dostrzega możliwość współpracy. Podczas studiów medycznych, a potem w trakcie wspinania się w hierarchii medycznej po szczeblach różnych specjalizacji i stopni naukowych, lekarze uczą się wielu nowoczesnych metod diagnostyki i terapii. Niestety w ramach tej nauki nie ma miejsca na wiedzę kliniczną i refleksję etyczną nad chorobami diagnozowanymi w okresie prenatalnym, których wyleczyć nie można"14 . Zdaniem (natomiast) Instytutu Ordo Iuris (opracowanie z 2016 roku) wielu ginekologów i położników nie kieruje pacjentki z zagrożoną letalnie ciążą do hospicjów perinatalnych, a w to miejsce przekazuje im informacje na temat możliwości usunięcia ciąży. Zatem istnieje paląca potrzeba, jak twierdzą specjaliści pro-live: „włączenia tematyki hospicjów prenatalnych do planu studiów wyższych - nie tylko kierunków medycznych, lecz także studiów z psychologii, teologii, pomocy socjalnej i socjologii"'15. Pytaniem zasadniczym jest nadal to, czy i jak będzie rozwijać się opieka perinatalna (paliatywna)? Czy otrzyma odpowiednie prawne, społeczne i religijne (moralne) wsparcie?

\section{Dynamizm opieki okołoporodowej}

Generalnie, w zakresie funkcjonowania opieki okołoporodowej, możemy mówić o zmianach, które idą w absolutnie dobrym kierunku. Ich zamierzeniem (jak się wydaje) jest to, aby kobiety znajdujące się w trudnej sytuacji z powodu zagrożonej ciąży, mimo wszystko nie chciały korzystać z prawa do aborcji (por. ustawa z 1993 roku), ale wsparte odpowiednią opieką ze strony państwa chciały urodzić dziecko, które (już w dalszej kolejności) zostanie poddane adekwatnej opiece. To o rządzie pani premier Beaty Szydło można powiedzieć, że jego filozofią było

14 J. Szymkiewicz-Dangel, Perinatalna opieka paliatywna - czy możliwa jest wspótpraca położników i neonatologów z hospicjami domowymi dla dzieci?, dz. cyt., s. 25; por. tamże, s. 26: „Lekarze udzielający prenatalnej konsultacji najczęściej nie wiedzą, że poza przerwaniem ciąży istnieje także możliwość opieki paliatywnej. Niejednokrotnie kobiety, które z racji swego światopoglądu nie chcą przerwać ciąży, pomimo nieuleczalnej choroby dziecka, nie znajdują zrozumienia u lekarzy położników. Wielu z nich nie przyjmuje do wiadomości, że urodzenie dziecka i pożegnanie się z nim jest dla tych rodzin pożądanym i najlepszym rozwiązaniem".

15 Tamże; por. E. Wiater, Hospicja dla nienarodzonych - wywiad z dr J. Dangel, „Imago”, 4 (2011), s. 22-24; T. Dangel, Wady letalne u noworodków - opieka paliatywna jako alternatywa wobec aborcji i uporczywej terapii, „Standardy Medyczne” 9 (2007), s. 108-110. 
to, aby nie tyle bezpośrednio zakazywać kobietom takiego prawa (bo to zawsze wzbudza niepotrzebne emocje, protesty, marsze itp.), ale je adekwatnie wspierać i edukować w duchu bezwzględnego poszanowania życia ludzkiego. To w myśl tego założenia (jak można mniemać) Sejm Polski 4.11.2016 r. uchwalił Ustawę o wsparciu kobiet w ciąży i rodzin „Za życiem”"16.

Postanowiono, że program „Za życiem”, który rząd miał przyjąć do 31 grudnia 2016 r., będzie mógł być skierowany do rodzin z dzieckiem z orzeczeniem niepełnosprawności w stopniu, tj. odpowiednio określonym w przepisach: lekkim, umiarkowanym i znacznym. Tym samym (w myśl niniejszej ustawy) przewiduje się, że ,z tytułu urodzenia się żywego dziecka z ciężkim i nieodwracalnym upośledzeniem albo nieuleczalną chorobą zagrażającą życiu, które powstały w prenatalnym okresie rozwoju dziecka lub w czasie porodu, przysługuje jednorazowe świadczenie w wysokości 4 tys. zł. Przewodnikiem rodzin po systemie wsparcia ma być asystent rodziny, którego zadaniem będzie koordynowanie dostępnej pomocy". Natomiast właściwym motywem dla uzyskania etycznego dobra proponowanych rozwiązań miałoby być zapewnienie, że: „nie jest to zapłata za urodzenie dziecka chorego, niepełnosprawnego, ale jest to pierwsza pomoc w takiej sytuacji”'17. Jest to wyjaśnienie ważne jak i pozytywne z punktu widzenia katolickiej (personalistycznej) etyki, afirmującej godność każdej istoty ludzkiej niezależnie od stanu zdrowia.

Jednakowoż, jeśli nawet hospicja perinatalne nadal funkcjonowałyby poza systemem opieki zdrowotnej (tj. opieramy się o dane na rok 2016) ${ }^{18}$, to pytaniem jest, czy istniałaby szansa dla nowych ustaleń w zakresie niniejszej sprawy? Jest to pytanie (jak się wydaje) otwarte, bowiem media (na tamten czas) podawały, iż to wiceminister Łanda miał zaprojektować właściwy system opieki perinatalnej w hospicjach (por. PAP/Rynek Zdrowia 22 października 2016). Dość istotną kwestią było tutaj to, że „Dr Tomasz Dangiel i prof. Joanna Szymkiewicz-Dangiel z Fundacji Warszawskie Hospicjum dla Dzieci w liście do premier Beaty Szydło proponowały, by to ich Fundacja przyznawała akredytacje innym placówkom. Padł także pomysł, by stworzyć ogólnopolską bazę danych rodzin, które deklarują chęć adopcji noworodka z zespołem Downa lub innymi złożonymi wadami

16 Ustawa z dania 4 listopada 2016 r. O wsparciu kobiet w ciąży i rodzin ,Za życiem”, Dz. U. r. 2016; poz. 1860; por. http://www.dziennikustaw.gov.pl/du/2016/1860/1.

17 Tamże; Ministerstwo Rodziny, Pracy i Polityki Społecznej, Wsparcie dla rodzin, https://www.mpips.gov.pl/aktualnosci-wszystkie/art,5538,8787,wsparcie-dla-rodzin.html (20.04.2017).

18 Hospicja perinatalne działaja poza systemem. Nie oceniaja, służa pomoca, https:// plus.dziennikbaltycki.pl/magazyn/a/hospicja-perinatalne-dzialaja-poza-systemem (31.10.2016). 
wrodzonymi”'19. Natomiast inni, jak np. przedstawiciele Ogólnopolskiego Forum Pediatrycznej Opieki Paliatywnej, nie godziły się na takie zwierzchnictwo. W piśmie do wiceministra Michałkiewicza argumentowali swój sprzeciw chociażby następująco: „taka sytuacja zapewni warszawskiemu hospicjum monopol na szkolenia i wydawanie certyfikatów oraz konsultowanie najtrudniejszych przypadków"20.

I tak, w zakresie opieki okołoporodowej, można mówić nie tylko o ciekawych (tj. dobrych) zmianach (np. o aktualnych propozycjach omawianych przez różnych ekspertów), ale i o trudnych wyzwaniach programowych, którym sprostanie nie będzie łatwe, tzn. może być ono realizowane przez długi okres. Tutaj można mieć na myśli przede wszystkim tzw. wyzwania edukacyjne. Przykładem narastających trudności, jakie program opieki nad nienarodzonym życiem ludzkim może napotykać, jest to, że w wielu ośrodkach akademickich studenci medycyny są kształceni w kierunku wykonywania zabiegu aborcji, czyli tak naprawdę w kierunku zabijania (tzn. przynajmniej w pewnym sensie). Bywa, że w planach studiów są organizowane ,warsztaty" z metod aborcyjnych. Jest to wynikiem m.in. tego, że proaborcyjne organizacje, jak „Medical Students for Choice”, mają prawo dostępu do uczelni medycznych. I czynią to pod znanymi z lewicowych manifestów eufemizmami: „zdrowie reprodukcyjne, prawo do wyboru i tym podobne itp.”21. To, w czym specjalizują się lewicowe organizacje, to postawa przeciwna życiu ludzkiemu w prenatalnej fazie rozwoju. Chodzi niniejszym o takie rzeczy w programie studiów jak: ,propaganda proaborcyjna, zajęcia promujące antykoncepcję i ubezpładnianie, wreszcie warsztaty ze stosowania metody próżniowej, czyli zabijania nienarodzonych poprzez odsysanie z macicy kilkutygodniowego dziecka"22.

Są też i inne wyzwania, które tym razem literatura przedmiotu określa jako: dyscyplinujace $i$ organizacyjne. Po prostu znamiennym typem wyzwań, które się pojawiają przed opieką okołoporodową, jest to, że w niektórych ośrodkach

19 Tamże; por. Ustawa z dania 4 listopada 2016 r. O wsparciu kobiet w ciąży i rodzin „Za życiem”, Dz. U. r. 2016; poz. 1860.

20 Tamże; por. M. Małkowska, Pokochać od poczatku, „Hospicjum to też życie”, 1 (2013), s. 12-13.

21 Studenci medycyny będa indoktrynowani w kierunku zabijania. W planach ,warsztaty" z metod aborcyjnych, https:/gloria.tv/article/m (2.09.2016).

22 Tamże; B. Kmieciak - Z. Szafrańska-Czajka, Raport. Perinatalna opieka hospicyjna: wizja, działania oraz wyzwania, dz. cyt., tamże, s. 4: „Istotnym elementem rozwoju nauk biomedycznych jest możliwość udzielania wsparcia również pacjentom, którzy jeszcze się nie narodzili. Wyrażona w art. 39 Kodeksu Etyki Lekarskiej zasada, zgodnie z którą „podejmując działania lekarskie u kobiety w ciąży, lekarz równocześnie odpowiada za zdrowie i życie jej dziecka". 
neonatologicznych brakuje właściwej organizacji i dyscypliny pracy (tzn. przynajmniej tak się może się wydawać zwykłemu obserwatorowi). W związku z czym należałoby systemowo dokonać niektórych zmian, np. kadrowych, finansowych, karnych, adekwatnie motywujących pracowników do uczciwej, odpowiedzialnej, empatycznej pracy. Mamy tu na myśli takie sytuacje jak ta, o której „głośno” informowały media w swoim czasie: „Kobieta w ósmym miesiącu ciąży zgłosiła się do szpitala, ponieważ przestała czuć ruchy dziecka; zdiagnozowano, że dziecko nie żyje. Według pacjentki i jej męża, z którymi rozmawiał reporter RMF (...), gdy rozpoczęła się akcja porodowa, kobiecie nie udzielono pomocy; pozostawiona bez opieki, urodziła na podłodze w jednej ze szpitalnych sal"23.

\section{Podstawowe wnioski}

We wnioskach w kwestii wyzwań, zagrożeń i rozwoju hospicyjnej opieki okołoporodowej warto (po pierwsze) nawiązać do stanowiska Instytutu Kultury Prawnej Ordo Iuris, które jest tożsame z tym, co w naturalny sposób się narzuca rozumowi (jak się wydaje), oświeconemu katolicką wiarą. To jego pracownicy są współautorami obywatelskiego projektu ustawy całkowicie zakazującej aborcji, pod którym zebrano ponad 100 tys. podpisów. Instytut ten stanowi grupa wybitnych prawników, która broni katolickich wartości chrześcijańskich w przepisach polskiego prawa. I to stąd mogą oni być punktem odniesienia dla wielu działań, jako koniecznych do wprowadzenia w opiece okołoporodowej (paliatywnej). Nadto ich stanowisko może być wyznacznikiem dla podobnych dokonań w innych krajach. Ważne, aby ludzie brali z siebie przykład i jednoczyli się w walce o prawa dzieci nienarodzonych. Powinno to dziać się począwszy od takich instytucji jak: edukacyjne, akademickie, uniwersyteckie, a skończywszy na hospicjach perinatalnych.

Po drugie wydaje się, że działania opieki okołoporodowej powinny uwzględniać następujące etyczne zasady: a) Hospicja perinatalne mają rozwijać adekwatne (tj. holistyczne) formy opieki nad rodziną i umierającymi noworodkami; b) Lekarze mają proponować ich działalność zamiast aborcji; c) Dziecko, które ma wadę

23 Skandaliczny poród w Starachowicach. Minister zdrowia zabrat głos, http:// fakty. interia.pl/polska/news-skandaliczny-porod-w-starachowicach-minister (5.11.2016); por. A. Jankowska-Rachel, Gdy dziecko w tonie matki jest chore, „Biuletyn Podkarpackiego Hospicjum dla Dzieci”, 1 (2014), s. 9; D. Kornas-Biela; Przeżycia związane z diagnostyka prenatalna a postawy wobec niej w literaturze przedmiotu, w: Z zagadnień psychologii prokreacyjnej, red. Bielawska-Batorowicz E. - Kornas-Biela D., Lublin 1992, s. 27-35. 
letalną ma prawo do śmierci w ramionach rodziców: matki i ojca ${ }^{24}$; d) Każdy rząd, w trosce o najwyższe dobre wspólne obywateli, jakim jest życie, powinien czuwać na medycznych uczelniach w taki sposób nad etyczną i profesjonalną edukacją lekarzy, aby nikomu nie pozwalać propagować proaborcyjnych idei.

Po trzecie, jeśli nawet autentyczne dobro osoby ludzkiej w przestrzeni dyskursu społecznego jest niestety zniekształcane różnymi formami poprawności politycznej, to i tak trzeba podkreślić, że i w takich bardzo niekorzystnych ideowo i politycznie warunkach udaje się działać na rzecz autentycznego (tzn. obiektywnego) dobra poczętej istoty ludzkiej. Działania obecnego rządu (PiS) mogą budzić nadzieję na rozwiązania, które przyczynią się do niewykonywania aborcji, np. eugenicznej. Słusznie można zakładać, że jeśli nie bezpośredni (np. ustawowy) zakaz aborcji, to postępowanie wzmacniające pomoc socjalną (której bezpośrednim następstwem są działania hospicjów perinatalnych), mogą mieć duży wpływ na wyobraźnię moralną kobiet, w perspektywie wydania na świat poczętego życia, nawet jeśli jest ono realnie zagrożone chorobą letalną. Jest to prospołeczne działanie, etycznie konieczne na obecne czasy, które absolutnie należy podejmować w Polsce, w Europie, i na całym świecie.

\section{Ks. Stanisław Bialy: Hospice as a form of perinatal care aimed at preventing the phenomenon of abortion}

\section{Summary}

The author, starting from the fact that for many women childbirth is a trauma that involves a dilemma: to give birth or to go through an abortion of a sick child, considers the role of perinatal hospices. He puts forward the suggestion that such centers help to prevent abortions. If a woman is left with such a great problem alone, she is likely to make the decision to radically solve the problem. If she receives appropriate spiritual and material support, she usually accepts the birth of the child, and then an appropriate farewell (not excluding, if she is a Christian, the Sacrament of Baptism). This is an important means of assistance that women can receive (supported by the social policy of the present Polish government). The alternative may be found in programs that propose abortion to such mothers as the only right solution. Abortion, however, does not solve the problem, but often

24 K. Szmyd - R. Śmigiel - B. Królak-Olejnik, Propozycje postępowania z noworodkiem w przypadku rozpoznania wady letalnej w okresie prenatalnym, „Pediatria Polska”, 89 (2014), s. 389-394; por. P. Krzemoński, Kobieta drugą ofiara aborcji, „Głos dla Życia”, 4 (2014). 
increases the mother's drama, adding subsequent consequences: moral, psychological and somatic.

Key words: abortion, perinatal hospice, state policy, maternal care, ethics

\section{Bibliografia}

Abrams S.Y. - Field T. - Scafidi F. - Prodromidis M., Newborns of depressed mothers, "Infant Mental Health Journal" 16(1995), s. 233-239.

Dangel T., Opieka paliatywna w onkologii dziecięcej, „Opieka Paliatywna nad dziećmi”, XIV(2006), s. 48-56.

Dangel T., Wady letalne u noworodków - opieka paliatywna jako alternatywa wobec aborcji i uporczywej terapii, „Standardy Medyczne” 9(2007), s. 108-110.

Depresja poporodowa - cała prawda, http://www.edziecko.pl/ciąża i poród (3.02.2015).

Hospicja perinatalne działaja poza systemem. Nie oceniaja, stuża pomoca, https:// plus.dziennikbaltycki.pl/magazyn/a/hospicja-perinatalne-dzialaja-pozasystemem (31.10.2016).

Hospicjum perinatalne Łodzi - fundacja Gajusz Łódź, http://www.gajusz.org.pl/ dla-potrzebujacych/hospicjum-perinatalne.

Jankowska-Rachel A., Gdy dziecko $w$ tonie matki jest chore, „Biuletyn Podkarpackiego Hospicjum dla Dzieci", 1(2014), s. 9.

Karta praw dziecka umierajacego, „Więź” 589(2007), s. 11-12.

Kmieciak B. - Szafrańska-Czajka Z., Raport. Perinatalna opieka hospicyjna: wizja, działania oraz wyzwania, Warszawa 2016.

Kornas-Biela D.; Przeżycia zwiazane z diagnostyka prenatalna a postawy wobec niej w literaturze przedmiotu, w: Z zagadnień psychologii prokreacyjnej, red. Bielawska-Batorowicz E. - Kornas-Biela D., Lublin 1992, s. 27-35.

Kornas-Biela D., Wokół początków życia ludzkiego, Warszawa 2002.

Krzemoński P., Kobieta druga ofiara aborcji, „Głos dla Życia”, 4(2014).

Krzyżanowska-Zbucka J., Problemy emocjonalne kobiet w okresie okołoporodowym, Warszawa 2008.

Konwencja o prawach dziecka, przyjęta przez Zgromadzenie Ogólne Narodów Zjednoczonych dnia 20 listopada 1989 r.; Dz. U. 1991 nr 120 poz. 526.

Medycyna perinatalna, red. Z. Słomko, t. 2, Warszawa 1989.

Kuczkowski K.M. - Drobnik L., Anestezjologia w położnictwie i medycynie perinatalnej. Zasady i praktyka, Warszawa 2009.

Małkowska M., Pokochać od początku, „Hospicjum to też życie”, 1(2013), s. 12-13. 
Ministerstwo Rodziny, Pracy i Polityki Społecznej, Wsparcie dla rodzin, https:// www.mpips.gov.pl/aktualnosci-wszystkie/art,5538,8787,wsparcie-dla-rodzin. html (20.04.2017).

Okres okołoporodowy, https://pl.wikipedia.org/wiki/Okresoko\%C5\%82oporodowy. Platforma działania i deklaracja pekińska: Czwarta Światowa Konferencja ws. Kobiet, Pekin 4-15 wrzesień 1995 r.; http://www. federa.org.pl/nasze-publikacje/broszury-ulotki-ksiazki/380-zdrowie-reprodukcyjne-kobiet (10.11.2010). Rosyjski raport o śmierci i ,moralności”: około 70\% ciąży kończy się aborcja, http://www.fokus.tv; http://www.pch24.pl/rosyjski-raport-o-smierci-i-moralnosci--okolo-70--ciaz-konczy-sie-aborcja (23.09.2016).

Rycerz E., Specjaliści: rodzi się coraz więcej dzieci z chorobami genetycznymi, https://parenting.pl/specjalisci-rodzi-sie-coraz-wiecej-dzieci-z-chorobami-genetycznymi (2017).

Studenci medycyny będa indoktrynowani w kierunku zabijania. W planach ,warsztaty" z metod aborcyjnych, https://gloria.tv/article/m (2.09.2016).

Skandaliczny poród w Starachowicach. Minister zdrowia zabrat głos, http://fakty.interia.pl/polska/news-skandaliczny-porod-w-starachowicach-minister(5.11.2016).

Szmyd K. - Śmigiel R. - Królak-Olejnik B., Propozycje postępowania z noworodkiem w przypadku rozpoznania wady letalnej w okresie prenatalnym, „Pediatria Polska", 89 (2014), s. 389-394.

Szot L., Powstanie i rozwój ruchu hospicyjnego, „Studia Warmińskie” XLVI (2009), s. $226-237$.

Szymkiewicz-Dangel J., Perinatalna opieka paliatywna - czy możliwa jest wspótpraca położników i neonatologów z hospicjami domowymi dla dzieci?, w: Opieka Paliatywna nad dziećmi, red. T. Dangel, Warszawa 2007, s. 25-28.

Wiater E., Hospicja dla nienarodzonych - wywiad z dr J. Dangel, „Imago”, 4(2011), s. 22-24.

Wiejak A., Sa alternatywy dla aborcji i pozostaja nieznane, „Moja Rodzina”, 12(2014), s. 12-14.

Ustawa z dania 4 listopada 2016 r. O wsparciu kobiet w ciąży i rodzin „Za życiem”, Dz. U. r. 2016; poz. 1860.

Zaremba J., Genetyczna diagnoza. Badania prenatalne w Polsce, „Panorama Medyczna", 2(2006), s. 12-15. 